\title{
Who Am I Online? Examining Voluntary Use as Symbolic-Collective Action
}

\author{
Rennie Naidoo \\ School of Information Technology, University of Pretoria, Pretoria, South Africa
}

\begin{abstract}
This article reports on a test of an integrated voluntary information technology use model that draws on social identity theory to extend the functional utility model of the user. User feedback on a health care insurance firm's electronic service in South Africa was analyzed qualitatively using pattern matching to test the model's propositions. While functional utility was found to be a significant determinant of voluntary information technology use, both functional utility and symbolic needs were significant for some user segments. Information technology research can benefit from further cross-fertilization with social identity theory to explain use patterns in different voluntary contexts. Providers seeking to move beyond functional utility should consider the symbolic needs of strategically important user segments to strengthen long-term relationships.
\end{abstract}

Keywords Functional utility benefits, IT continuance, social identity theory, symbolic benefits, voluntary use

Two major research streams have advanced our understanding of information technology (IT) use. The individualistic stream focuses on demographic, attitudinal, psychographic, and technological characteristics (Venkatesh, Thong, and Xu 2012; Dabholkar and Bagozzi 2002; Bhattacherjee 2001b; Bitner, Brown, and Meuter 2000; Rogers 1995; Davis 1989). It emphasizes cognitive explanations that link individual knowledge, attitudes, and beliefs to use practices (Venkatesh and Thong 2012; Rogers 1995; Ajzen 1991; Davis 1989) and takes a functional utility perspective (Venkatesh, Davis and Morris 2007; Venkatesh, Morris, Davis, and Davis 2003; Goodhue and Thompson 1995). Overall, these studies assume that variations in

Address correspondence to Rennie Naidoo, School of Information Technology, University of Pretoria, Pretoria, South Africa. E-mail: rennie.naidoo@up.ac.za opinions and values between users point to interindividual differences.

While this research has been valuable in providing important insights into individual factors, even those working within the paradigm that informs it have called for a broader understanding of social relations (Bagozzi 2007; Straub and Burton-Jones 2007; Bagozzi and Lee 2002, Moon and Kim 2001). However, the subsequent inclusion of social pressure and other cultural factors in these studies has yielded limited insights (Ma and Agarwal 2007; Lee, Lee, and Lee 2006; Venkatesh and Davis 2000, Venkatesh, Morris, Davis, and Davis 2003). Some researchers point out that attempts to incorporate the social with narrow constructs (e.g., group pressure) do not fully capture social influence (Lee, Lee, and Lee 2006). Furthermore, these studies limit the socially rich nature of voluntary IT use to a moderating factor defined by a single scale item.

The social stream emphasizes the systematic analysis of social, relational, and cultural forces (Walsh, Kefi, and Baskerville 2010; Gallivan and Srite 2005, Castells 1999). Against the backdrop of large-scale voluntary IT through which old social groups are resurfacing and new ones are emerging, calls for greater sensitivity to social influences (Stanworth and Hsu 2012; Herold 2010; Lamb and Kling 2003). For instance, social media researchers have observed strong identity influences on informal online/mobile social networks such as blogs and twitter (Yardi and Boyd 2010).

Although these two research streams have considered the role of identity, they have tended to only touch on it (Venkatesh, Thong, and $\mathrm{Xu} 2012$; Lee, Lee, and Lee 2006). They have not considered the possibility that identity might be playing a much more central role. One notable exception is the work of Roberta Lamb and her collaborators, which focuses on the role-related interpersonal ties between individuals - also known as the relational self-and IT use (Lamb and Davidson 2005; Lamb 2006; Lamb and Kling 2003). However, it provides limited insight into the role of the collective self, for example, gender, race, and ethnicity (White and Dahl 2006). Lamb 


\section{R. NAIDOO}

and Davidson (2005) did call for further investigation in broader contexts to theorize the notion of identity.

This study focuses on users of a South African health care insurance firm's (HIC) electronic service (eHIC) and also traditional options such as call centers, intermediary support branches, and walk-in centers. HIC's managers had hoped that the e-service would develop into the dominant channel. Despite their efforts, it failed to attract and retain a critical mass of users.

From the research standpoint, this case is of interest on three counts:

1. It is a case of voluntary information technology use, wherein firms provide options for modalities for interaction to the users, who then exercise their discretion to choose their preferred modality. It is quite different from mandated information technology use, wherein users are forced to participate in a prescribed manner, which has been the primary focus of research thus far (Lee, Lee, and Lee 2006; Venkatesh and Davis 2000).

2. User retention is a key problem plaguing many IT providers. Prominent examples include Blackberry, MySpace, and Friendster (Gartner 2013, Nielsen 2009). From a practical standpoint, the benefit of user retention is appealing to voluntary IT providers (Rayport and Bernard 2005; Reichheld and Schefter 2000).

3. Research shows that voluntary IT is often an important symbolic resource for users. It fulfills their selfdefinition needs such as social status, status achievement, prestige, position, distinctiveness, exclusivity, and belongingness (Yardi and Boyd 2010; Katz and Sugiyama 2006; Moon, Li, Jo, and Sanders 2006; Turkle 1995; Belk 1988, Nach and Lejeune 2010; Cheung and Lee 2010). However, only a few authors have drawn on social identity theory (SIT) concepts to understand motivations such as the need to maintain or enhance one's identity (Lee, Lee, and Lee 2006). Research has largely focused on how IT fulfills user's functional utility needs (Venkatesh, Thong, and Xu 2012; Bhattacherjee 2001a; Davis 1989).

The HIC case study provides us with an opportunity to examine the extent to which IT use is influenced by functional utility and symbolic needs. That understanding can be used to increase user retention and improve voluntary IT use. If symbolic needs strengthen long-term bonds with users, providers could develop designs informed by that insight.

This article has two objectives: (1) develop an integrated model of voluntary use, by deriving major propositions from a synthesis of both functional utility and social identity perspectives; and (2) empirically test the integrated model in a voluntary use context. The rest of the article describes the development of this integrated model and investigates its explanatory potential.

\section{INCLUSION OF SOCIAL IDENTITY PERSPECTIVE}

Social identity theory has been applied in social psychology and organizational behavior to understand employees' identification with their organizations (Alvesson, Ashcraft, and Thomas 2008; Alvesson and Willmott 2002; Ibarra 1999; Ashforth and Mael 1989) and in market research to explain customer identification with firms, services, and brands (Lam, Ahearne, Hu, and Schillewaert 2010; Homburg, Wieseke, and Hoyer 2009; Bhattacharya and Sen 2003; Reed 2002). It provides concepts to expand current IT use research to social contexts where users rely on broader identity positions.

In voluntary IT contexts it is plausible that users belonging to different social groups represent themselves and their mission differently, and identify with specific values and norms that distinguish them. These types of contexts are more likely to be defined by intergroup rather than individual or interpersonal characteristics (Hinds and Mortensen 2005; Bargh and McKenna 2004), as illustrated by the following two examples. Users may use IT to demonstrate group membership and to mark their position in a group (Stanworthand Hsu 2012; Belk 1988; Tajfel 1974). The symbolic meanings of IT may be integral not only in expressing one's own identity and membership in social groups, but also in perceiving the identity of others (Christopher and Schlenker 2004; Dittmar 1992; Goffman 1978). This preoccupation with similarity and difference is at the core of identification processes, yet IT use research seems to privilege individual differences and to underplay the importance of similarity in collective identity processes. Notwithstanding efforts to integrate identity into the mainstream theories of IT use (Cheung and Lee 2010), social identity itself remains underutilized in IT use research, despite its analytical importance.

This article advances cross-fertilization between two related fields of inquiry. It supports the notion that users evaluate the functional utility of an IT. However, it proposes that users are also motivated by symbolic needs linked to their specific group identities. Correspondingly, it suggests that a model that incorporates both functional utility and social identity needs will yield a richer explanation of voluntary IT use.

\section{TOWARD AN INTEGRATION OF PERSPECTIVES ON VOLUNTARY IT USE}

The first literature of interest is centered on the information systems continuance model (Bhattacherjee 2001b), which draws on the technology acceptance model (TAM) 
(Venkatesh and Davis 2000) and user satisfaction research (Oliver 1980) to explain user loyalty. One of the major building blocks of the information systems continuance model is the concept of "IT continuance," defined as the postacceptance stage of IT use when the use of the IT "becomes part of the user's normal routine behavior" (Bhattacherjee 2001b, 352). This model, which sees that users are individualistic and rational actors, is based on the notion that congruence between the user's expectation and actual performance of the IT is an important predictor of the user's satisfaction with the IT. It views satisfaction as an affective property, defined as the users' feelings (affect) or emotions.

The second literature of interest is centered on Tajfel's (1978) social identity theory. Tajfel defines social identity as "that part of an individual's self-concept which derives from his knowledge of his membership of a social group (or groups) together with the value and emotional significance attached to that membership" $(1978,63)$. It highlights a cognitive component (group knowledge), an evaluative component (positive or negative evaluation of the group), and an emotional component (positive or negative emotions with the evaluation) (Trepte and Krämer 2008).

According to Hogg and Terry (2000), social categorization processes play a key role in creating and defining an individual's place in society. People categorize themselves as members of various social categories (gender, ethnicity, occupation, and other more transient groups) and form prototypes ${ }^{1}$ by depersonalizing ${ }^{2}$ self-perception (similar to stereotyping) and by accentuating prototypical similarities among in-group members and prototypical differences with out-group members (Hogg and Reid 2006; Hogg 2001a). In doing so, their self-conception and norms (i.e., attitudes, feelings and behaviors) are guided by their prototype and they do not have to have strong interpersonal ties to perceive themselves as members of a group (Hogg 2001a). In the case of IT use, when group membership is salient, use behavior to a significant degree will be directed by group norms (Bagozzi and Lee 2002; Hogg and Tindale 2005), and users are likely to be attracted to IT designs that accord with their group norms (Bhattacharya and Sen 2003).

Self-continuity refers to people's needs to maintain a stable and consistent sense of self over time and across situations (He, Li and Harris 2012). Since stability and constancy are important to users, they are likely to maintain self-consistency by taking on IT embedded with norms that match their sense of self (Cheung and Lee 2010).

Self-distinctiveness refers to people's need to distinguish themselves positively from others in a social context (Hogg and Reid 2006). The users are therefore likely to use IT that helps them resolve the tension between the need to be similar and different from others in a desired way.
Self-enhancement refers to people's need to view themselves in a positive light (Bhattacharya and Sen 2003). IT that matches the norms the user values can also help the user maintain, affirm, enhance, and protect his or her selfesteem.

Similar to user satisfaction theory, social categorization theory (SCT) also accounts for the affective state (feelings) of the user (Haslam, Branscombe, and Bachmann 2003; Bergami and Bagozzi 2000). However, SCT suggests that people experience emotions as a consequence of their group membership (Kuppens and Yzerbyt 2012). Following this, the appraisal of group norms inscribed and embedded in the IT can elicit emotions that operate at the group rather than the individual level. For instance, threat to group norms (e.g., nonavailability of content in the user's heritage language) can lead to negative emotions such as anger or disappointment (Giles and Reid 2004; Bailey 1997). We can therefore expect negative emotional reactions (dissatisfaction) when an IT does not cater for the salient social identity of the user.

\section{INTEGRATED VOLUNTARY TECHNOLOGY USE MODEL}

The integrated voluntary technology use (IVTU) model (Figure 1) integrates conceptual elements of the dominant theories just discussed and builds further by factoring in the influence of social identity on functional utility benefits and the symbolic needs of users. The model is based on the notion that the user's evaluation of normative similarities and differences between the firm's ideal user prototype (design target) and the user's prototype (salient collective self) influences voluntary IT adoption and use.

Perceived usefulness is defined as the functional utility benefits of the IT. Symbolic value is defined as the sociopsychological benefits that motivate users to continue IT use. Technology identification is defined as the user's perception of the expected symbolic benefits of technology use that satisfies one or more of the user's salient selfdefinitional (i.e., who am I) need(s). In this model, selfdefinition is not limited to the personal self but extends to the social prototypical self. Together these concepts are expected to offer a richer explanation of use in a voluntary IT context. (Operational definitions of these concepts are detailed in the data analysis section.)

The IVTU model places "social identity" as a central issue in IT voluntary use behavior. Based on this model, the following two propositions are advanced:

Proposition 1: Positive user-technology identification decision path. Users making positive appraisals about their social identity normative expectations of an IT tend to confirm normative expectations that are 
R. NAIDOO

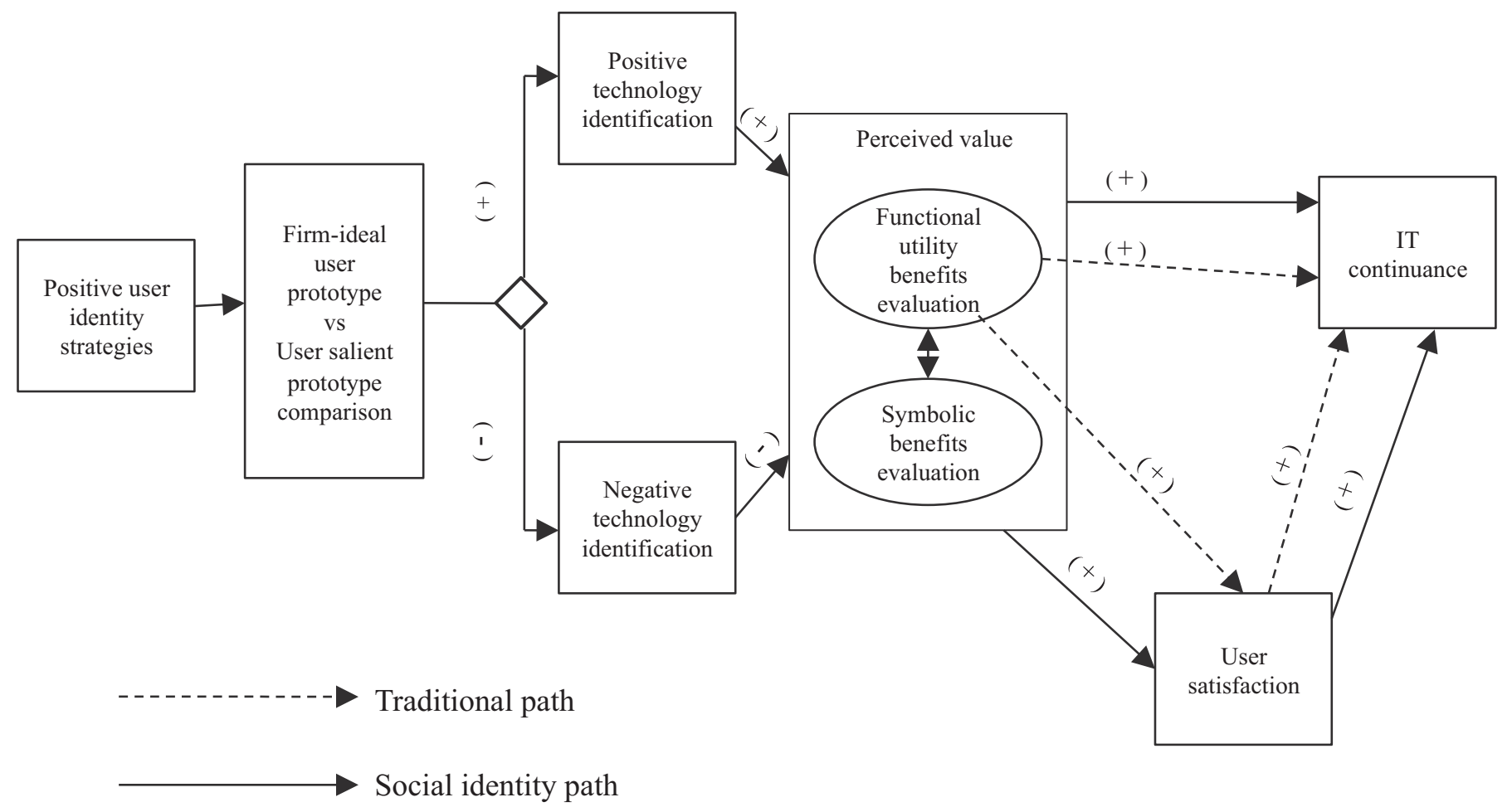

FIG. 1. Integrated voluntary technology use model.

similar to the firm's prototypical user, and are more likely to express a positive perception of the symbolic and functional utility benefits of the IT, and consequently express satisfaction with the IT.

Proposition 2: Negative user-technology identification decision path. Users making negative appraisals about their social identity normative expectations of an IT are likely to express either a distorted or a diminished perception of the symbolic and functional utility benefits of the IT, and consequently express dissatisfaction with the IT.

In case-study research, it is also important to test the countertheory. Therefore the following proposition is advanced:

Proposition 3: If their individual functional utility needs are met (not met), users are more likely to express satisfaction (dissatisfaction) by making positive (negative) appraisals of the IT and by displaying positive (negative) affective reactions to it.

\section{METHODOLOGY}

A single embedded case study design was used to test the proposed model.

Several units of analysis were included to draw reasonable conclusions from the observations. The user was the most important unit of analysis. Other important units of analysis included competing service channels and members of the e-service design team.

Since this study focuses on users who used their collective identity to appraise the e-service, the sample was not meant to be random or representative of the wider population, but purposeful (Patton 1990).

Two primary sources of evidence were analyzed. First, HIC's e-service user feedback log of over 5000 responses since inception of the e-service in1999 to 2006 was used. The advantage of this data set-which is relatively uncommon in IT use research-is that it records behavior in a natural context.

Second, field research was carried out in three different periods, 3 months in mid 2005, 3 months in late 2005, and another month in late 2006. Here a total of 21 semistructured interviews were conducted with the designers. Those interviewed included members of the management team, business/systems analysts, usability analysts, Java developers, system architects, graphic designers, subject-matter experts including a stress counselor and dietician, a marketing team member, and two call-center team leaders. Although there were no set boundaries for selecting the interviewees, informants who had a longer history with the e-service were sought. A few "newcomers" were invited to provide more balance. 
A protocol was used to ensure that the interview process was consistent. Interviewees were probed with questions such as:

What were goals of the e-service? Did the e-service achieve those goals?

Which users use the system regularly and why?

Did usage change over time? If so, in what way? And why do you think this is the case?

What events appear to trigger more use? Describe the patterns of these events?

Have there been any surprises in terms of users' use the system compared with its intended purpose? Clarify by means of an example?

All 21 interviews were tape-recorded and fully transcribed. Notes were taken during the interviews and additional observations were noted immediately after each interview was concluded. The two primary sources of evidence were supplemented with secondary data from internal documents, management reports, prior research with internal and external parties, presentations, the organization's publications, technical documents and internal reports, a review of the e-service functionality, and a sample of recorded calls handled by online call center support team. Some of these sources were important for the historical reconstruction of the case. Version 5 of ATLAS.ti was used for the overall management of the research project and the data. This archive consisted of field notes, documents, quantitative data, and other electronic files generated. ATLAS.ti maintained a chain of evidence to support the study's conclusions (Darke, Shanks, and Broadbent 1998).

The guidelines suggested by Miles and Huberman (1994) were used for the qualitative data analysis. First, the interview transcripts and documents were analyzed to understand the firm and design team's perspectives on the prototypical user and IT use issues in general. The data were scanned to identify norms typically associated with a profit-seeking firm-such as reducing capital and operating costs, increasing profitability through cross-selling and up-selling, increasing service performance, and improving customer relationships.

Second, the Website feedback responses were subjected to an initial scan to gather key nouns that may reflect salient user identities using an open coding process (such as "we," "spouse," "they," "language," "Mac"). Third, an independent judge coded the user feedback data using the following coding frame derived from the research model:

- Scan for influential group identities of the informants (1, prototypical user, 2, personal identities, 3 , social identities).

- Scan for group appraisals made by informants (1, positive in-group, 2, positive out-group, 3 , negative in-group and 4 , negative out-group).
- Scan if the IT presented a threat or opportunity to their group norms (1, positive, 2 , negative, 3 , neutral).

- Scan for informant's appraisal of the IT's functional/utility benefits (1, positive, 2 , negative, 3 , neutral).

- Scan for informant's appraisal of the IT's symbolic value (1, positive, 2 , negative 3 , neutral).

- Scan for informant's overall IT appraisal (1, positive, 2, negative, 3 , neutral).

- Scan for affective reactions associated with these appraisals (e.g., 1, positive, 2, negative 3, neutral/indifferent),

The coder also annotated the response lists with prespecified values. For instance, values for general salient social categorizations included familial roles, occupational roles, relational roles, gender identity, ethnic identity, national identity, community, peer groups, and spokespersons (Reed and Forehand 2007). Values for normative threats and opportunities included personal rights, group values, psychological safety, reciprocity, and trust relations (Neuberg and Cottrell 2008). Overall emotions were captured as positive (satisfied), indifferent, or negative (dissatisfied). Values for specific emotions included negative (anger, fear, dislike, disgust, disappointment) and positive reactions (joy, love, pleasure, excitement) (Kuppens and Yzerbyt 2012; Kuppens, Yzerbyt, Dandache, Fischer, and van der Schalk 2013). Values for functional utility benefits included functional and task-related benefits such as time savings, compensatory rewards, and convenience (Bhattacherjee 2001a; Bitner, Brown and Meuter 2000). Values for symbolic benefits included social approval and positive self-esteem needs such as social status, status achievement, prestige, position, exclusivity, and belongingness (He, Li and Harris 2012; Bhattacharya and Sen 2003).

The limitation of a theory-guided research process is that it may introduce strong bias, as here a researcher finds evidence in support of a theory. Since the main source of data for this study is the user feedback log, participants could not have been given cues to answer in a certain way or to agree with the questions to please the researcher. Nevertheless, to improve the neutrality of the results, an academic not familiar with social identity theory acted as an auditor and reviewed the category and operational definitions before the study. Another academic also blind to the purpose of the study coded 20 randomly chosen excerpts, assigning 18 to the same categories the independent judge and researcher assigned, yielding a 90 percent level of agreement. This check provided reasonable verification of the accuracy of the coding. These validated values and categories were refined so that a simpler and more efficient list was used to test the model. Finally, 


\section{R. NAIDOO}

key informants - two managers and one call centre support staff-verified the analysis and confirmed that the social identity categories identified covered key areas of customer dissatisfaction.

\section{RESULTS}

The initial development of eHIC began in the latter part of 1999, when excitement about dotcoms was at its zenith. The head of eHIC then said in a local press release:

I have no doubt that eHIC is destined for great success ... eHIC is in the strong position of being able to leverage off the strong and well respected HIC name. This will give eHIC a good head start and should assist in accelerating the growth of our client base. (press release, May 10, 2000)

The firm envisaged providing over eHIC a wide range of services that were then being offered through the traditional call-center and intermediary channels. Tools to manage health care such as online statements, health care savings account balances, benefits information, personal detail changes, hospital preauthorization, claims submissions, and tracking were implemented. A lifestyle portal was implemented to "prevent disease and improve their wellbeing." Members could also earn rewards in the form of "wellness points" for using the e-service. The accumulation of these points provided tangible benefits such as cheaper access to fitness facilities, cheaper airline tickets, and holiday accommodations.

Over the years eHIC appealed mostly to younger users (see Table 1). Although more than 90 percent of eHIC's members were enrolled in the wellness rewards program, the use of the e-service declined once the novelty wore off. After only 3 months of modest use, around 75 percent of registered users discontinued use of e-service. This is in stark contrast to the lapse rate of only 3 to 4 percent of HIC policy holders (indicating high loyalty to the firm). In effect, only 25 percent of the registered users remained loyal and habitual users of the online channel.

Meanwhile, the use of the call center remained relatively high with repeat calls accounting for a significant component of the call volume. (Internal statistics summarized in Table 2 show that 40 percent of members called more than once a month.) Even though there were valiant efforts such as marketing promotional campaigns and a major redesign of the service to move usage of eHIC to $40 \%$ of registered users, the proportion of active registered members hovered around the $25 \%$ mark for the next 2 years.

eHIC had only small pockets of success. Overall its usage was sporadic and tapering and its discontinuance rate was high. By 2005, the firm gave up the notion of eHIC as a dominant channel and decided to integrate it with other service channels. During this drive to "merge all
TABLE 1

Summary of key user characteristics

\begin{tabular}{lc}
\hline Subject & Measures \\
\hline Registration based on & \\
gender & \\
Male & $53 \%$ \\
Female & $47 \%$ \\
Active use based on & \\
gender & \\
Male & $48 \%$ \\
Female & $52 \%$ \\
Registered user age & \\
group & \\
20-25 & $22 \%$ \\
26-30 & $32 \%$ \\
$31-35$ & $24 \%$ \\
36-40 & $7 \%$ \\
$\quad 40-45$ & $8 \%$ \\
Greater than 45 & $7 \%$ \\
Preferred language of & \\
registered users & \\
English & $56 \%$ \\
Afrikaans & $44 \%$ \\
Wellness & \\
Health insured members & \\
on Wellness program & \\
Wellness members as & \\
part of online & \\
registered user base & \\
\hline
\end{tabular}

Note. Source: Internal management report. The majority of the users appear to be younger and affiliated with the wellness program. The measure of active use is based on logins per month.

channels," the e-service was viewed as a complementary channel-just one of many channels to interact with the firm. One of the senior managers in charge of the e-service operations commented:

I think if we look today at where we have come our initial objective was to convert a channel (call centre) into another channel (e-service). And lessons are learnt that you know this is a social environment okay. There is no dominant channel. It's apparent to me that the channels are interlinked merged and one will use whatever is closest in proximity.

Despite providing strong incentives, eHIC was unable to build a critical mass of users. It remains to be seen whether the high discontinuance (low loyalty) patterns of the health care insurer's e-service users will change in the future. For now, the propositions tested next provide insights into the high ratio of user discontinuance. 
VOLUNTARY USE AS SYMBOLIC-COLLECTIVE ACTION

TABLE 2

Average service levels achieved in relation to client interactions

\begin{tabular}{|c|c|c|}
\hline Channel & Volume & Service level \\
\hline Service center & $\begin{array}{l}35,000 \text { calls } \\
\text { per day }\end{array}$ & $\begin{array}{l}86 \% \text { answered within } \\
20 \text { seconds; } 96 \% \text { of } \\
\text { queries resolved } \\
\text { during the call }\end{array}$ \\
\hline Walk-in centers & $\begin{array}{r}5000 \text { clients } \\
\text { per month }\end{array}$ & $\begin{array}{l}\text { Average waiting time: } \\
2 \text { minutes, } 40 \\
\text { seconds }\end{array}$ \\
\hline $\begin{array}{l}\text { Correspondence } \\
\text { (e-mails, faxes, } \\
\text { letters received) }\end{array}$ & $\begin{array}{l}1280 \text { per } \\
\text { day }\end{array}$ & $\begin{array}{l}\text { Response within } \\
8 \text { hours }\end{array}$ \\
\hline Interactive website & $\begin{array}{c}7000 \text { logins } \\
\text { per day }\end{array}$ & $99.27 \%$ uptime \\
\hline $\begin{array}{l}\text { Queries channeled } \\
\text { through employer or } \\
\text { intermediary }\end{array}$ & $\begin{array}{c}5000 \text { per } \\
\text { month }\end{array}$ & $\begin{array}{l}93 \% \text { resolved in } \\
24 \text { hours }\end{array}$ \\
\hline
\end{tabular}

Note. Source: HIC's Consolidated Financial Report.

\section{Proposition 1: Examining the Positive IT Identification Path}

Overall, three user social categories were judged to have the patterns for the positive user-IT identification path (see the shaded part of Table 3 for more details). These social categories point to the increasing grip firms have in shaping group and individual identifications. The discussion here also provides a sense of theory-guided thematic pattern-matching technique applied to online feedback data.

User-self-service identification. The first group showed higher identification with the e-service and preferred not to engage with a call-center agent or the other traditional channels. The following quote captures their mindset:

\begin{abstract}
I am so excited [Affective Reaction: Positive]about the fact that I can actually keep track of my claims online [Utility Value: Positive], that I just had to tell you how great this is!!!!!!!!! I hate to use the phone [Traditional Chanel Identification: Negative], but love to go online [Symbolic Value: Positive] [Technology Identification: Positive]!!! Thank you for a great opportunity that you give to your members [Overall IT Appraisal: Positive]!!
\end{abstract}

Customer-firm identification. Similar to the findings of Bhattacharya and Sen (2003), the second group showed high-identification with the firm. These users generally tended to express their satisfaction with the e-service.
This site is very helpful easy to use [Utility Value: Positive]. I am very happy with it cause I am able to access my statements policy details etc I love it [Affective Reaction: Positive]. You the Best HIC [Firm Identification: Positive]!

User-wellness program identification. Members of the third group appeared to identify strongly with the firm's wellness rewards program. They had positive views about the e-service as it enhanced the overall value proposition of the wellness program.

\begin{abstract}
At this stage I am very happy with the site [Affective Reaction: Positive] just wish I could earn more points for logging on as I try and keep updated almost twice a week but have reached the maximum points for the year [Utility Value: Positive]. Maybe you could also start looking at getting for eg. motivational speakers etc and give wellness members points for attending seminars or workshops like these [Wellness Program Identification: Positive]. Keep it up I have never enjoyed and looked forward to going onto the site [Technology Identification: Positive] as much as I do every time! Thanks very much for your efforts and continuous new ideas.
\end{abstract}

The evidence suggested that the majority of the members of the wellness program were "rewards chasers," who sought to upgrade their status by exploiting the "easy" rewards instead of making "real" lifestyle changes (Arnesen, Fleenor, and Toh 1997). As noted by one of the systems architects, a new norm started holding sway in the firm:

\begin{abstract}
And Wellness is kind of moving away from just the Web, you know. I think we have been fairly Web centric. Now they have said ... no, for nutrition, you have got to go and see a nutritionist, which I agree with [Adjusted: Firm Prototypical Norm]. There are certain things that we are not very good at, for the Web [Self-service Identification: Negative]. You are not going to go to the gym on the web. You are going to go to the gym near you, physically, you know, physical [Traditional Channel Identification: Positive].
\end{abstract}

To some extent, these users did fit the characteristics of the firm's prototypical ideal user, as they wished to maintain a relationship with the firm via the cost-effective e-service channel. They also exhibited little desire to call the call center. Furthermore, they showed strong affinity for the wellness rewards program.

\section{Proposition 2: Examining the Negative IT Identification Decision Path}

Although more social categories were judged to have followed the negative user-IT identification decision path, here the discussion is limited to six salient social identity categories.

User-traditional channel identification. In this first group, the majority of users identified strongly with traditional channels instead of the e-service. The excerpt 
TABLE 3

Summary of thematic pattern matching results

\begin{tabular}{|c|c|c|c|c|c|c|c|c|}
\hline Analysis category & $\begin{array}{c}\text { Social } \\
\text { identification } \\
\text { category }\end{array}$ & $\begin{array}{c}\text { User matches design } \\
\text { target prototype's } \\
\text { norms }\end{array}$ & $\begin{array}{c}\text { Negative } \\
\text { technology } \\
\text { identification }\end{array}$ & $\begin{array}{c}\text { Positive } \\
\text { technology } \\
\text { identification }\end{array}$ & $\begin{array}{l}\text { Overall IT } \\
\text { appraisal }\end{array}$ & $\begin{array}{l}\text { IT symbolic } \\
\text { value }\end{array}$ & $\begin{array}{c}\text { IT } \\
\text { functional/utility } \\
\text { value }\end{array}$ & $\begin{array}{l}\text { IT affective } \\
\text { reactions }\end{array}$ \\
\hline \multirow[t]{2}{*}{$\begin{array}{l}\text { Traditional channel } \\
\text { identification }\end{array}$} & $\begin{array}{l}\text { Call center } \\
\text { identification }\end{array}$ & No & Yes & No & $\begin{array}{l}\text { Mainly } \\
\text { negative to } \\
\text { neutral }\end{array}$ & $\begin{array}{l}\text { Negative to } \\
\text { mainly } \\
\text { neutral }\end{array}$ & $\begin{array}{l}\text { Mainly negative } \\
\text { to neutral }\end{array}$ & $\begin{array}{l}\text { Mainly } \\
\text { negative to } \\
\text { indifferent }\end{array}$ \\
\hline & $\begin{array}{l}\text { Health care } \\
\text { practitioner } \\
\text { identification }\end{array}$ & No & Yes & No & $\begin{array}{l}\text { Mainly } \\
\text { negative to } \\
\text { neutral }\end{array}$ & $\begin{array}{l}\text { Negative to } \\
\text { mainly } \\
\text { neutral }\end{array}$ & $\begin{array}{l}\text { Mainly negative } \\
\text { to neutral }\end{array}$ & $\begin{array}{l}\text { Mainly } \\
\text { negative to } \\
\text { indifferent }\end{array}$ \\
\hline \multirow[t]{2}{*}{$\begin{array}{l}\text { Technology } \\
\text { identification }\end{array}$} & $\begin{array}{l}\text { Technology Brand } \\
\text { identification } \\
\text { (Mac users) }\end{array}$ & No & Yes & No & $\begin{array}{l}\text { Mainly } \\
\text { negative to } \\
\text { neutral }\end{array}$ & $\begin{array}{l}\text { Mainly } \\
\text { negative to } \\
\text { neutral }\end{array}$ & Negative & $\begin{array}{l}\text { Mainly } \\
\text { negative to } \\
\text { indifferent }\end{array}$ \\
\hline & $\begin{array}{l}\text { Self-service } \\
\text { identification }\end{array}$ & Yes & No & Yes & Positive & $\begin{array}{l}\text { Neutral to } \\
\text { mainly } \\
\text { positive }\end{array}$ & Positive & $\begin{array}{l}\text { Mainly } \\
\text { positive }\end{array}$ \\
\hline \multirow[t]{2}{*}{ Firm identification } & $\begin{array}{l}\text { Firm brand } \\
\text { identification }\end{array}$ & Partially & Mainly no & Mainly yes & $\begin{array}{l}\text { Mainly } \\
\text { positive }\end{array}$ & $\begin{array}{l}\text { Neutral to } \\
\text { mainly } \\
\text { positive }\end{array}$ & Mainly positive & $\begin{array}{l}\text { Mainly } \\
\text { positive }\end{array}$ \\
\hline & $\begin{array}{l}\text { Wellness Program } \\
\text { Identification }\end{array}$ & Partially & Mainly no & Mainly yes & $\begin{array}{l}\text { Mainly } \\
\text { Positive }\end{array}$ & $\begin{array}{l}\text { Neutral to } \\
\text { mainly } \\
\text { positive }\end{array}$ & Positive & $\begin{array}{l}\text { Mainly } \\
\text { Positive }\end{array}$ \\
\hline $\begin{array}{l}\text { Gender } \\
\text { identification }\end{array}$ & $\begin{array}{l}\text { Familial role } \\
\text { identification } \\
\text { (spouses) }\end{array}$ & No & Yes & No & $\begin{array}{l}\text { Mainly } \\
\text { negative to } \\
\text { neutral }\end{array}$ & $\begin{array}{l}\text { Mainly } \\
\text { negative }\end{array}$ & Mainly negative & $\begin{array}{l}\text { Mainly } \\
\text { negative to } \\
\text { indifferent }\end{array}$ \\
\hline $\begin{array}{l}\text { Ethnic } \\
\text { identification }\end{array}$ & $\begin{array}{l}\text { Heritage language } \\
\text { identification }\end{array}$ & No & Yes & No & $\begin{array}{l}\text { Mainly } \\
\text { negative to } \\
\text { neutral }\end{array}$ & $\begin{array}{l}\text { Mainly } \\
\text { negative to } \\
\text { neutral }\end{array}$ & $\begin{array}{l}\text { Mainly negative } \\
\text { to neutral }\end{array}$ & $\begin{array}{l}\text { Mainly } \\
\text { negative to } \\
\text { indifferent }\end{array}$ \\
\hline $\begin{array}{l}\text { Chronic illness } \\
\text { identification }\end{array}$ & $\begin{array}{l}\text { Illness } \\
\text { identification } \\
\text { (AIDS patients) }\end{array}$ & No & Yes & No & $\begin{array}{l}\text { Mainly } \\
\text { negative to } \\
\text { neutral }\end{array}$ & $\begin{array}{l}\text { Mainly } \\
\text { negative to } \\
\text { neutral }\end{array}$ & $\begin{array}{l}\text { Mainly negative } \\
\text { to neutral }\end{array}$ & $\begin{array}{l}\text { Mainly } \\
\text { negative to } \\
\text { indifferent }\end{array}$ \\
\hline
\end{tabular}




\section{VOLUNTARY USE AS SYMBOLIC-COLLECTIVE ACTION}

shown next is typical of the thematic patterns associated with this negative user-IT identification path. Here the user provides a positive appraisal of the rival call center channel:

\section{Dealing with your Call Centre guys is JUST GREAT [Tra- ditional Channel Identification: Positive] ... once you give them the membership number [Symbolic Value: Positive] they have the information on their fingertips [Utility Value: Positive]. Also the folks just seem to be enjoying what they're doing ... a pleasure to deal with [Affective Reaction: Posi- tive].}

A number of users in this category reported dissatisfaction with the registration and log-in process. They contrasted it with the ease of the call-center process. Moreover, they valued the personalized service. Rewards alone were not enough to change their propensity.

User-health care practitioner identification. In the second group, rewards could not deter the users from discontinuing use of the e-service. The firm's dietician thus describes the importance of nuanced interpersonal interaction in the dietetic practice:

\begin{abstract}
I mean online, on the tool I could have had two men who were trying to lose weight and exercising three times a week [Technology Identification: Negative]. One could have been a bachelor who was a complete perfectionist and working very long hours and travelling a lot. One could have been a retired man who had lots of time on his hands and had his own vegetable garden in the back and lived out on the coast [Distinctive User Prototypes]. You know or something like that ... Those are the kind of things, the small nuances that are important, to bear in mind because of the fact that this eating is something we all do every day and it is highly emotive and so highly affected by the type of life that you lead [Traditional Channel Identification: Positive].
\end{abstract}

These two groups continued to value interpersonal and face-to-face interactions with call-center service consultants and health care practitioners, respectively.

User-heritage language identification. The third group, whose heritage languages were excluded from the e-service, also followed the negative user-IT identification path. Social identity theorists have pointed out that language is an integral constituent of how social identity differentiates a group from other relevant out-groups (Giles 1977; Giles and Reid 2004). A number of users suggested that their heritage language is central to their identity, a sentiment captured by the following quotes:

Could you please dilute your language ... not every member is highly educated to can understand your oxford English [Heritage Language Identification]. the purpose here is to transmit info and not to impress via language protocol or style [Utility Value: Negative] ... [E-service language: Negative] ... [Affective Reaction: Negative]
Geen Afrikaans? Hoe dan nou mense? Of is ek blind? Eke is seker amper die helfte van julle kliente praat Afrikaans. (Roughly retranslated: No Afrikaans? How come people? I must be blind? [Affective Reaction: Negative] I am sure at least half of your client base speaks Afrikaans [Symbolic Value: Negative] [Heritage Language Identification].)

It would be nice if we had the information in another African Language (e.g., zulu or shangaan) [Symbolic Value: Negative] [Heritage Language Identification]. It's not easy for me to find what we are looking for [Utility Value: Negative] in this somewhat difficult language [Affective Reaction: Neutral].

Despite having customers with strong heritage language identification (Table 1 shows that for $44 \%$ of registered users, preferred language was Afrikaans), HIC continued to use only English on its e-service because of efficiency considerations and also "political correctness." Provision of eHIC content on all the 11 official languages of South Africa would have added to the cost. Moreover, if HIC provided eHIC with content in some languages and not in others, it would upset groups that were invested in the excluded languages. Although the e-service was restricted to English, call-center consultants could speak multiple languages, as almost all of them were bilingual/multilingual.

User-familial role identification. The fourth group, whose traditional roles were not accommodated by the design, also led users down the negative user-IT identification path. For instance, women who identify themselves strongly as "steward" of household health care were put off by the terminology and value system of the eHIC environment, which imposed their legal role definitions (main member and beneficiaries) of their health insurance contracts. These excerpts illustrate how women presented their dissatisfaction:

My husband is the main member. He does not do the internet thing ... he does not do the computer thing because he works and does not have the time for nitty gritty things [Utility Value: Negative]. I have to do it [Familial Role Identification: Negative]. I am his spouse and you are just wasting time trying to contact him to register [Symbolic Value: Negative]. Why on earth can I not do the registering? I don't know why you even waste your time to have a website. This is a shocking service you have [Affective Reaction: Negative].

I have been an avid fan [Technological Identification: Positive] of the site over the last year, but I am disappointed [Affective Reaction: Negative] to find that it does not give me access to the nutrition centre - as a spouse dependent [Familial Role Identification: Negative]. Although my husband is the principal member, I am the one checking on statements and making use of facilities such as HIC baby [Utility Value: Negative] [Symbolic Value: Negative] ... why the access denials? 


\section{R. NAIDOO}

User-chronic illness identification. The fifth group, whose chronic illness needs were not accommodated by the design, also led users down the negative user-IT identification path. For example, because of stigma, individuals are uneasy about accessing HIV prevention, testing, treatment, and care in public spaces (Bond, Chase, and Aggleton 2002; Burris 1999; Parker and Aggleton 2003). Although IT can empower stigmatized individuals by providing them with access to information in a private space, the preventative health care tools in eHIC appeared to be too generic and oriented toward relatively healthy members. Here again the design team excluded users with chronic medical conditions. Their frustrations were along the following lines:

\section{For the moment I have only one thing to ask and that is why as a person with HIV [Chronic Illness Identification], I should not be registered as part of the Wellness Med program. I must have missed it somewhere, but I didn't find anything conducive to make me join [Symbolic Value: Negative], as $\mathrm{HIV}$ is according to HIC a Chronic Illness. Surely, it should also be part of the program?}

Given the high prevalence of HIV/AIDS in South Africa, the wellness tool could have been used to provide education about specific nutrition information to those afflicted by it.

User-technology brand identification. The sixth group that went down the negative user-IT identification path was of users especially skilled and adept at using IT. Moreover, they have a stronger affinity, fondness, and devotion to it. They were alienated by the technological features of the system. For example, users of Mac (Macintosh) computers strongly identify with their brand, and this is how they define themselves as a group in society (Kahney 2002). The following excerpt illustrates how a Mac user strategically presented his group identity instead of his individual identity to challenge the firm for not catering to his in-group's needs:

\begin{abstract}
I'm very disappointed [Affective Reaction: Negative] in the fact that your site only supports PC users. Surely you must have many Apple Mac users too [Technology Brand Identification] and I think you should have implemented your new site with them in mind [Symbolic Value: Negative]. I cannot access my claims [Utility Value: Negative] from my mac as I was able to before you revamped this site. And it is quite frustrating [Affective Reaction: Negative]. I trust you have the plans in the pipeline to accommodate your Mac users?
\end{abstract}

Initially, the Mac platform, by virtue of the size of the market and technical resource constraints, was ignored by eHIC. Given the high status of Mac users, HIC was later pressured into prioritizing fixes and ensuring its operating platform and browser standards did not constrain these "valued" users.

\section{Proposition 3: Examining the Counter Functional Utility Theory Decision Path}

Following Lee (1989), a single instance of disconfirming evidence (functional utility patterns explaining dissatisfaction without the presence of social identity factors) is sufficient to empirically refute the first two propositions. Results from user responses showed strong functional utility patterns only (see Table 3 ). The following excerpt is illustrative of such a pattern:

\begin{abstract}
My impressions of the site are greatly influenced by the speed [Utility Value]. There is really no point if it takes me half an hour to navigate the site! I have just spent the last 20 minutes (!!!) trying to check claim information [Utility Value: Negative]. I love the fact that I can but I am generally irritated and frustrated by the length of time it takes [Affective Reaction: Negative]. I think that the portal should be simplified allowing for greater speed and access to services [Utility Value: Negative]. Links can be used to supply extraneous information. The service is really innovative but the truth is that it is more convenient for me at this point to phone the call centre [Traditional Channel Identification: Positive]!
\end{abstract}

Here the e-service does not meet the user's functional utility expectations whereas the alternative channel does.

This excerpt together with the universal support for functional utility factors indicated in Table 3 (users also emphasized functional utility factors in their appraisal of the e-service even when they expressed symbolic needs) does not wholly invalidate the proposed integrated model, but suggests only partial support.

\section{IMPLICATIONS}

This study set out to conceptualize and test an integrated voluntary IT use model that incorporates functional utility and social identity (symbolic) needs. This model was expected to yield a richer explanation of voluntary IT use. The findings confirm that functional utility and symbolic needs were significant for some user groups. However, there was stronger empirical support for functional utility as the more significant determinant of user satisfaction. While the evidence does not generally corroborate the integrated model, symbolic needs were present for some users and those effects here seemed to be as significant as functional utility needs. But it appears that symbolic needs representative of group norms do not always inform the normative concerns of users. Nevertheless, the case-study evidence is informative because it suggests that users can be motivated by differing mixes of functional utility and symbolic needs. Therefore, the researchers and practitioners would be prudent, while prioritizing functional utility needs, to give consideration to the symbolic needs, especially to those of strategically important user groups. 
In the mandated IT use domain, firms have generally invested heavily in ensuring compliance behaviors and preventing resistance behaviors. However, in the context of voluntary use-apart from meeting the user's functional utility needs-firms sometimes need to appeal to users' symbolic aspirations as group members (a better wife, a loyal member of an ethnic group, a stigmatized and chronically ill person), if they wish to attract, build, and retain a critical mass of active users. IT design can be counterproductive to this goal if it resorts to excessive depersonalization of target users, or if it is uncompromising in molding target users to comply with the firm's norms and goals. The present research should sound the alarm bell to firms that impose their conception of the prototypical ideal user (in the present case, an English-speaking, avid health and fitness-oriented insurance client) on their clients and are not sensitive to their varied needs.

In a voluntary IT use context, members of a psychologically salient group are in a better position to challenge the firm for not meeting their symbolic needs. They can reject the firm's IT, use more accommodating service channels (e.g., HIC's call centers), or adopt the better suited IT of a competing firm (Stanworth and Hsu 2012). Designers should expand their requirements determination processes to cater to these symbolic needs when such user groups are strategically important. They should be wary of characterizing lost users as "problematic" and disaffected groups as "non adopters," "late adopters," and "technology-anxious" users (Parasuraman and Colby 2001; Rogers 1995). Following SIT, it is often more appropriate to view disaffected users as a collective and by the identity salience that defines them in a particular use context. To better manage users on the negative user-IT identification path, designers should recognize that the choice of the IT might be tied to a salient social identity of the user. In this way, designers can focus on opportunities that may arise from satisfying the distinctive needs of these social groups instead of bypassing or simply ignoring them. Understanding the processes by which IT come to symbolize social identities for social groups may assist designers in influencing, and further confirming, the social images and meanings through the use of the IT. In this sense, users are induced to see their social identities as linked to a particular IT and its symbolic cues, and make their usage decisions accordingly.

Designers should also proactively assess the norms of major user groups and the extent to which these norms exert a strong influence on IT use. Some voluntary IT may also be vehicles for the user to validate aspects of their group identity. As shown, a user with a disregarded heritage language may be motivated to use alternative service channels more accommodating of that user's identity. Furthermore, IT can end up being a barrier (Yardi and Boyd 2010). As shown, a stigmatized user, such as an HIV/AIDS patient, should not be ignored, as such users may be more willing to interact with an electronic self-service channel because of the anonymity it offers. Designers should expect such users to consider important social identity needs when evaluating whether or not they should adopt a voluntary IT.

Although functional utility remains a significant predictor of use in a voluntary context, the role of social identity and the extent to which it can exert a significant influence over a user's behavior should not be underestimated. However, as for all normative designs, drawing mindlessly on social identities can also create problems. Given the open and situated character of voluntary IT use, more work needs to be done on how to prioritize designs that serve symbolic needs. More work is also needed to understand the social and ethical implications of designs that use social identity categorizations to profile users.

By drawing on SIT, this study has provided a new way to conceptualize the role of social influence on voluntary IT use. Use is seen here not only as individual action but also as a form of symbolic collective action (Cheung and Lee 2010). SIT has provided an expanded view and offered more specifics on how voluntary IT use can also be an outward expression of the user's identity, and a means of signifying group membership and identification.

\section{CONCLUSION}

This study introduces to the IT researcher's and practitioner's toolkit the user's identification with the firm's voluntary IT as an important complementary variable to traditional IT user acceptance and continuance frameworks that are based on a functional utility perspective.

Although the study found functional utility to be generally more significant in influencing user satisfaction, symbolic needs appear to be at least equally as strong for users with salient reference group memberships. The study also provides useful insights into how voluntary IT firms could allocate their design resources to cater to the needs of these users. Important, unobserved user heterogeneity - in the form of different social categorizations-is likely to exist among users of voluntary IT. Therefore, as opposed to only using demographic and psychographic profiles, designers could segment strategically important user groups into homogeneous social categorizations to fulfill their mix of functional utility and symbolic needs and improve long-term relationships.

This study has made an initial attempt to use SIT's conceptual richness to deepen understanding of processes related to voluntary IT use. Some of the ideas presented here call for further research into social identity and IT use. Given the pervasiveness of IT and the large number of applications now available in the voluntary use context, there are opportunities to explore more advanced social identity 


\section{R. NAIDOO}

processes at work. After all, a number of contemporary IT applications involve implicit or explicit salient reference group memberships. For instance, research could investigate other voluntary contexts such as virtual communities to test the relative importance of functional utility and social identity needs. Alternative research approaches such as surveys, ethnographies, action research, and experiments could also be used. Finally, we need to broaden our conceptualization of "users" to include the "social" in the "individual," to better understand use in voluntary IT contexts.

\section{NOTES}

1. Hogg (2001b) describes prototypes as the user's cognitive representations of group norms. Group norms are regularities in attitudes and behavior that characterize a social group and differentiate it from other social groups (Hogg and Reid 2006).

2. Depersonalization does not view users as unique and multifaceted individuals but as matches to the relevant prototype (Hogg 2001b).

\section{REFERENCES}

Ajzen, I. 1991. The theory of planned behavior. Organizational Behavior and Human Decision Processes 50(2): 179-211.

Alvesson, M., and H. Willmott. 2002. Producing the appropriate individual: Identity regulation as organizational control. Journal of Management Studies 39(5): 619-44.

Alvesson, M., K. Ashcraft, and R. Thomas. 2008. Identity matters, Reflections on the construction of identity scholarship in organization studies. Organization 15(1): 5-28.

Arnesen, D. W., C. P. Fleenor, and R. S. Toh. 1997. The ethical dimensions of airline frequent flier programs. Business Horizons 40(1): 47-55.

Ashforth, B., and F. Mael. 1989. Social identity theory and the organization. Academy of Management Review 14(4): 20-39.

Bailey, B. 1997. Communication of respect in interethnic service encounters. Language in Society 26(3): 327-56.

Bargh, J. A., and K. Y. McKenna. 2004. The Internet and social life. Annual Review Psychology 55: 573-90.

Bagozzi, R. P. 2007. The legacy of the technology acceptance model and a proposal for a paradigm shift. Journal of the Association for Information Systems 8(4): 244-54.

Bagozzi, R. P., and K. H. Lee. 2002. Multiple routes for social influence: the role of compliance, internalization, and social identity. Social Psychology Quarterly 65(3): 226-47.

Belk, R. W. 1988. Possessions and the extended self. Journal of Consumer Research 15(2): 139-68.

Bergami, M., and R. P. Bagozzi. 2000. Self-categorization, affective commitment, and group self-esteem as distinct aspects of social identity in the organization. British Journal of Social Psychology 39(4): 555-77.

Bhattacharya, C. B., and S. Sen. 2003. Consumer-company identification: A framework for understanding consumers' relationships with companies. Journal of Marketing 67(2): 76-88.
Bhattacherjee, A. 2001a. An empirical analysis of the antecedents of electronic commerce service continuance. Decision Support Systems 32: 201-14.

Bhattacherjee, A. 2001b. Understanding information systems continuance: An expectation-confirmation model. MIS Quarterly 25(3): 351-70.

Bitner, M. J., S. W. Brown, and M. L. Meuter. 2000. Technology infusion in service encounters. Journal of the Academy of Marketing Science 28(1): 138-49.

Bond, V., E. Chase, and P. Aggleton. 2002. Stigma, HIV/AIDS and prevention of mother-to-child transmission in Zambia. Evaluation and Program Planning 25(4): 347-56.

Burris, S. 1999. Studying the legal management of HIV-related stigma. American Behavioral Scientist 42(7): 1229-43.

Castells, M. 1999. The information age: Economy, society and culture, Vol. II: The power of identity. Cambridge, MA: Blackwell.

Cheung, C. M., and M. K. Lee. 2010. A theoretical model of intentional social action in online social networks. Decision Support Systems 49(1): 24-30.

Christopher, A. N., and B. R. Schlenker. 2004. Materialism and affect: The role of self-presentational concerns. Journal of Social and Clinical Psychology 23(2): 260-72.

Dabholkar, P. A., and R. P. Bagozzi. 2002. An attitudinal model of technology-based selfservice: Moderating effects of consumer traits and situational factors. Journal of the Academy of Marketing Science 30(3): 184-201.

Darke, P., G. Shanks, and M. Broadbent. 1998. Successfully completing case study research: Combining rigour, relevance and pragmatism. Information Systems Journal 8(4): 273-89.

Davis, F. D. 1989. Perceived usefulness, perceived ease of use, and user acceptance of information technology. MIS Quarterly 13(3): 319-39.

Dittmar, H. 1992. The social psychology of material possessions: To have is to be. Hemel Hempstead, UK: Harvester Wheatsheaf.

Gallivan, M., and S. Srite. 2005. Information technology and culture: Identifying fragmentary and holistic perspectives of culture. Information and Organization 15: 295-338.

Gartner. 2013. Market share analysis: Mobile phones, worldwide, 4Q12 and 2012. Retrieved from Gartner's website at http://www.gartner.com/resId=2334916 (accessed January 15, 2014).

Giles, H. 1977. Language, ethnicity and intergroup relations. London, UK: Academic Press.

Giles, H., and S. A. Reid. 2004. Language: Intergroup parameters. In The concise Corsini encyclopedia of psychology and behavioral science, ed. W. E. Craighead and C. Nemeroff, 510-12. Chichester, UK: Wiley.

Goffman, E. 1978. The presentation of self in everyday life. Harmondsworth, UK: Penguin.

Goodhue, D. L., and R. L. Thompson. 1995. Task-technology fit and individual performance. MIS Quarterly 19(2): 213-27.

Haslam, A., N. Branscombe, and S. Bachmann. 2004. Why consumers rebel. Social identity and the etiology of adverse reactions to service failure. In Social identity at work. Developing theory for organizational practices, ed. A. Haslam, D. van Knippenberg, M. J. Platow, and N. Ellemers, 293-309. New York, NY: Psychology Press.

Herold, D. K. 2010. Imperfect use? ICT provisions and human decisions: An introduction to the special issue on ICT adoption and user choices. The Information Society 26(4): 243-46. 


\section{VOLUNTARY USE AS SYMBOLIC-COLLECTIVE ACTION}

He, H., Y. Li, and L. Harris. 2012. Social identity perspective on brand loyalty. Journal of Business Research 65(5): 648-57.

Hinds, P., and M. Mortensen. 2005. Understanding conflict in geographically distributed teams: The moderating effects of shared identity, shared context, and spontaneous communication. Organization Science 16(3): 290-307.

Hogg, M. A. 2001a. A social identity theory of leadership. Personality and Social Psychology Review 5: 184-200.

Hogg, M. A. 2001b. Social categorization, depersonalization, and group behavior. In Blackwell handbook of social psychology: Group processes, ed. M. A. Hogg and R. S. Tindale, 56-85. Oxford, UK: Blackwell.

Hogg, M. A., and R. S. Tindale. 2005. Social identity, influence, and communication in small groups. In Intergroup communication: Multiple perspectives, ed. J. Harwood and H. Giles, 141-64. New York, NY: Peter Lang.

Hogg, M. A., and S. A. Reid. 2006. Social identity, self-categorization, and the communication of group norms. Communication Theory 16(1): 7-30.

Hogg, M. A., and D. I. Terry. 2000. Social identity and selfcategorization processes in organizational contexts. Academy of Management Review 25(1): 121-40.

Homburg, C., J. Wieseke, and W. D. Hoyer. 2009. Social identity and the service-profit chain. Journal of Marketing, 73(2): 38-54.

Ibarra, H. 1999. Provisional selves: Experimenting with image and identity in professional adaptation. Administrative Science Quarterly 44: 764-91.

Kahney, L. 2002. Mac loyalists: Don't tread on us. Wired, December 2.

Katz, J. E., and S. Sugiyama. 2006. Mobile phones as fashion statements: Evidence from student surveys in the US and Japan. New Media \& Society 8(2): 321-37.

Kuppens, T., and V. Y. Yzerbyt. 2012. Group-based emotions: The impact of social identity on appraisals, emotions, and behaviors. Basic and Applied Social Psychology 34(1): 20-33.

Kuppens, T., V. Y. Yzerbyt, S. Dandache, A. H. Fischer, and J. van der Schalk. 2013. Social identity salience shapes group-based emotions through group-based appraisals. Cognition \& Emotion 27(8): 1359-77.

Lam, S. K., M. Ahearne, Y. Hu, and N. Schillewaert. 2010. Resistance to brand switching when a radically new brand is introduced: A social identity theory perspective. Journal of Marketing 74(6): 128 46.

Lamb, R. 2006. Alternative paths toward a social actor concept. In Proceedings of the Americas Conference on Information Systems, 4113-23. http://aisel.aisnet.org/cgi/viewcontent.cgi?article=2041\& context=amcis2006 (accessed March 18, 2013)

Lamb, R., and E. Davidson. 2005. Information and communication technology challenges to scientific professional identity. The Information Society 21(1): 1-24.

Lamb, R., and R. Kling. 2003. Reconceptualizing users as social actors in information systems research. MIS Quarterly 27(2): 197-235.

Lee, A. S. 1989. A scientific methodology for MIS case studies. MIS Quarterly 13: 33-50.

Lee, Y., J. Lee, and Z. Lee. 2006. Social influence on technology acceptance behavior: Self-identity theory perspective. The DATA BASE for Advances in Information Systems 37: 2-3.

Ma, M., and R. Agarwal. 2007. Through a glass darkly: Information technology design, identity verification, and knowledge contribution in online communities. Information Systems Research 18(1): 4267.

Miles, M. B., and A. M. Huberman. 1994. Qualitative data analysis, 2nd ed. Thousand Oaks, CA: Sage.

Moon, J. W., and Y. G. Kim. 2001. Extending the TAM for a WorldWide-Web context. Information \& Management 38(4): 217-30.

Moon, J., J. Li, S. Jo, and G. Sanders. 2006. Improving quality of life via blogs and development of a virtual social identity. Journal of Information Technology Management 17(3): 26-37.

Nach, H., and A. Lejeune. 2010. Coping with information technology challenges to identity: A theoretical framework. Computers in Human Behavior 26(4): 618-29.

Neuberg, S. L., and C. A. Cottrell. 2008. Managing the threats and opportunities afforded by human sociality. Group Dynamics 12(1): 63-72.

Nielsen. 2009. Nielsen's Social Media QuickTake: May 2009. Retrieved from Nielsen's website at http://www.nielsen.com/content/ dam/corporate/us/en/newswire/uploads/2009/06/nielsen_pr_090619 .pdf (accessed January 15, 2014).

Oliver, R. L. 1980. A cognitive model of the antecedents and consequences of satisfaction decisions. Journal of Marketing Research 17: 460-69.

Parasuraman, A., and C. L. Colby. 2001. Techno-ready marketing: How and why your customers adopt technology. New York, NY: Simon and Schuster.

Parker, R., and P. Aggleton. 2003. HIV and AIDS-related stigma and discrimination: A conceptual framework and implications for action. Social Science \& Medicine 57(1): 13-24.

Patton, M. Q. 1990. Qualitative evaluation and research methods, 2nd ed. Newbury Park, CA: Sage.

Rayport, J. F., and J. J. Bernard. 2005. Best face forward: Why companies must improve their service interfaces with customers. Boston, MA: Harvard Business School Press.

Reed, A. 2002. Social identity as a useful perspective for self-conceptbased consumer research. Psychology and Marketing 19(3): 23566.

Reed, A., and M. Forehand. 2007. Managing social identity: Strategies for creating brand identification and community (Working paper): Philadelphia, PA: The Wharton School, University of Pennsylvania.

Reichheld, F. F., and P. Schefter. 2000. E-Loyalty: Your secret weapon on the Web. Harvard Business Review July-August: 105-13.

Rogers, E. M. 1995. Diffusion of innovations, 3rd ed. New York, NY: Free Press.

Trepte, S., and N. Krämer. 2008. Expanding social identity theory for research in media effects: Two international studies and a theoretical model. Report retrieved from http://psydok.sulb.unisaarland.de/volltexte/2008/2341 (accessed January 12, 2014).

Stanworth, J. O., and R. S. Hsu. 2012. Conceptualizing the interdependent social actor in self-service technology adoption. Paper presented at the 12th International Research Conference in Service Management, La Londe les Maures, France, May 29-June1.

Straub, D., and A. Burton-Jones. 2007. Veni, vidi, vici: Breaking the TAM logjam. Journal of the Association for Information Systems 8(4): 223-29.

Tajfel, H. 1974. Social identity and intergroup behaviour. Social Science Information 13(2): 65-93.

Tajfel, H. E. 1978. Differentiation between social groups: Studies in the social psychology of intergroup relations. New York, NY: Academic Press. 


\section{R. NAIDOO}

Turkle, S. 1995. Life on the screen: Identity in the age of the Internet. New York, NY: Simon \& Schuster.

Venkatesh, V., and F. D. Davis. 2000. A theoretical extension of the technology acceptance model: Four longitudinal field studies. Management Science 46(2): 186-204.

Venkatesh, V., F. D. Davis, and M. G. Morris. 2007. Dead or alive? The development, trajectory and future of technology adoption research. Journal of the Association for Information Systems 8(4): 268-86.

Venkatesh, V., M. G. Morris, G. B. Davis, and F. D. Davis. 2003. User Acceptance of Information Technology: Toward a Unified View. MIS Quarterly 27(3): 425-78.
Venkatesh, V., J. Thong, and X. Xu. 2012. Consumer acceptance and use of information technology: Extending the unified theory of acceptance and use of technology. MIS Quarterly 36(1): 157-78.

Walsh, I., H. Kefi, and R. Baskerville. 2010. Managing culture creep: Toward a strategic model of user IT culture. Journal of Strategic Information Systems 19(4): 257-80.

White, K., and D. W. Dahl. 2006. To be or not be? The influence of dissociative reference groups on consumer preferences. Journal of Consumer Psychology 16(4): 404-14.

Yardi, S., and D. Boyd. 2010. Dynamic debates: An analysis of group polarization over time on twitter. Bulletin of Science, Technology \& Society 30(5): 316-27. 